easy comprehensibility of the relevancy doctrine, there remains a conscious feeling that additional safeguards to one's privacy are requisite.

Perhaps the extension of the Gouled rule into the field of wiretapping and other secretive hearing devices would be desirable. It is in this field that safeguards to the search are lacking, there being no necessity for obtaining search warrants. A more rigorous application of the rule in the sedition area may also be advisable. But shortcomings to this rule may render any application ineffec-. tive, because the rule leaves officers in the dark as far as knowledge of the precise limits to seizure is concerned. There exists the additional question of whether such a judicial rule would have any real deterrent effect upon law enforcement officers. In addition to these two practical objections to the extension of ${ }^{*}$ the rule into other areas, there is the further objection that the Gouled rule lacks an acceptable rationale. But this objection is not necessarily decisive. As Justice Learned Hand has said, "Such constitutional limitations arise from grievances, real or fancied, which their makers have suffered, and should go pari passu with the supposed evil. They withstand the winds of logic by the depth and toughness of their roots in the past. ${ }^{365}$

\title{
COMMUNISTS AND THE RIGHT TO BAIL
}

The usually tranquil law of bail has been recently disturbed by a surprising number of cases illustrating the sharp test put to civil liberties conceptions by the Communist problem. Proceedings against subversives under the Smith Act ${ }^{1}$ and the Internal Security Act of $1950^{2}$ have brought variations in previously routine and unquestioned bail procedures. Within the bail framework, constitutional values and practical possibilities of martyrdom compete with concern for the security of the nation. The haven offered by sympathetic foreign governments and the nature of the international Communist conspiracy seem to promote escape. ${ }^{3}$ The government's challenge of the traditional rules of bail has raised difficult problems of policy and justice.

It is the purpose of this comment to examine the response of the federal courts to these considerations in four situations regarding bail: (1) prior to conviction; (2) pending appeal; (3) in deportation proceedings; and (4) in examining the qualifications of a proffered surety. ${ }^{4}$

${ }^{65}$ United States v. Kirschenblatt, 16 F. 2d 202, 203 (C.A. 2d, 1926).

154 Stat. 670 (1940), as amended, 62 Stat. 808 (1948), 18 U.S.C.A. 2385 (1951).

264 Stat. 987 (1950) (Subversives Activities Control Act of 1950; the McCarran Act).

${ }^{3}$ Gerhardt Eisler jumped bail and was, until his recent removal from office, an important official in the East German government. As stated in Stack v. Boyle, 342 U.S. 1, 5 (1951), "The government asks the courts to depart from the norm by assuming, without introduction of evidence, that each petitioner is a pawn in a conspiracy and will, in obedience to a superior, flee the jurisdiction." But compare the reception of the same argument when advanced in a deportation proceeding.

4 In relating the cases, it may be helpful to keep in mind the following sequence of events which have seemed to tighten the government's case: outbreak of Korean hostilities, June 25, 
I

Because the Judiciary Act of 1789 gave an absolute right to bail in noncapital cases, ${ }^{5}$ the federal courts have never had to decide whether or not the right is one guaranteed by the Eighth Amendment. However, the Eighth Amendment clearly governs the amount of bail by directing that "excessive bail shall not be required." In regard to this command, it has been stated: "The reasonableness of the amount is to be determined by properly striking a balance between the need for a tie to the jurisdiction and the right to freedom from unnecessary restraint before conviction under the circumstances surrounding each particular accused."

In the recent case of Stack $v$. Boyle, the district court, acting after the flight of four of the defendants in Dennis v. United States, ${ }^{7}$ departed from the usual considerations in determining amount and set the recognizance at $\$ 50,000$ for each of twelve defendants charged with violation of the Smith Act. ${ }^{8}$ After the hearing on the defendants' motion to reduce bail, the court based its decision upon the only evidence offered by the government, "that four persons previously convicted under the Smith Act in the Southern District of New York had forfeited bail."' The Court of Appeals found the district court's ruling not clearly erroneous..$^{10}$ Reversing, the Supreme Court remanded and ruled that in the absence of a hearing with special evidence as to each defendant individually,

1950; opinion of the Supreme Court in Dennis v. United States, 341 U.S. 494 (1951), upholding the constitutionality of the Smith Act, June 4,1951; and the flight of four of the Dennis defendants, July 2, 1951, N.Y. Times, p. 1, col. 1 (July 4, 1951).

5 The case of Rowan v. Randolph, 268 Fed. 527 (C.A. 7th, 1920), held that even a record of prior escapes does not justify denial of bail. Today this right is given meaning in the Federal Rules of Criminal Procedure which provide: Rule 46(a)(1). "A person arrested for an offense not punishable by death shall be admitted to bail" before conviction.

- United States ex rel. Rubinstein v. Mulcahy, 155 F. 2d 1002, 1004 (C.A. 2d, 1946). Rule 46(c), Fed. Rules Crim. Proc., provides: "Amount. If the defendant is admitted to bail, the amount thereof shall be such as in the judgment of the commissioner or court or judge or justice will insure the presence of the defendant, having regard to the nature and circumstances of the offense charged, the weight of the evidence against him, the financial ability of the defendant to give bail and the character of the defendant."

7 341 U.S. 494 (1951).

8342 U.S. 1 (1951). These defendants have since been found guilty in the district court. N.Y. Times, p. 1, col. 2 (Aug. 6, 1952).

- Ibid., at 3. The four were Hall, Thompson, Winston and Green. Hall has since been apprehended and convicted, while serving sentence, of contempt for jumping bail. United States v. Hall, 198 F. 2d 726 (C.A. 2d, 1952).

${ }^{10}$ Stack v. Boyle, 192 F. 2d 56 (C.A. 9th, 1951). After the motion to reduce bail had been denied in the District Court, the defendants applied for a writ of habeas corpus. After a hearing, the District Court denied this petition. The Court of Appeals affirmed on the ground that an appeal of the motion to reduce, not a petition for a writ of habeas corpus, was the proper remedy. This affirmation was on the alternative ground that the finding of the District Court was not clearly erroneous. 
the unusual amount could not be squared with the statutory and constitutional standards.11 The issue to be determined in such a hearing is what amount will insure the presence of the defendant and still give him a chance to remain free until conviction. Where proper consideration of these factors in relation to each defendant is absent, discretion is abused. ${ }^{2}$

This decision of the Supreme Court is in line with the usual treatment of discretionary powers of a trial judge: a determination of a discretionary question without reference to the purpose of the right in question is abuse of discretion, is error, and is reversible error if prejudicial..$^{13}$ In the Stack case, the district judge had, in effect, tried to supplement the authorized procedure for restricting and prosecuting Communists by setting the amount of the bail bond unusually high. Under the Supreme Court ruling, if the prosecution desires a high bail bond it must carry the burden of proving the need for special inducement to insure the presence of the accused. ${ }^{14}$

The force of this decision in preventing the detention of Communists by arbitrary judicial action can best be seen by following the case back to the trial judge to see the difficulties encountered by him as he tried to conform to the standards set by the Supreme Court and, at the same time, to affirm the $\$ 50,000$ amount for each defendant. ${ }^{15}$ When the defendants in the Stack case again moved to reduce bail, Judge Mathes held an extensive hearing on evidence relative to each defendant. The judge, in his opinion, gave prolonged consideration to each of the factors set out by the statute to be relevant.16 Quoting at length from the opinion of Chief Justice Vinson in Dennis v. United States on the dangers of Communists, he found the amount to be reasonable.

But this time the Court of Appeals did not affirm the denial of the motion to reduce. ${ }^{17}$ Instead, they reduced the amount to $\$ 10,000$ or less for each defendant, holding that the government had failed to show the necessary special circumstances. The Court of Appeals attacked the reasoning of Judge Mathes at three points. He had inferred the reasonable probability of guilt merely from the fact

11 The Supreme Court agreed that habeas corpus was not the proper method of raising the question but considered the merits of the defendants' claim anyway, pointing out the necessity for speed in bail proceedings.

${ }^{12}$ Stack v. Boyle, 342 U.S. 1, 5 (1951): "Bail set at a figure higher than an amount reasonably calculated to fulfill this purpose is 'excessive' under the Eighth Amendment."

${ }^{13}$ See, e.g., Styria v. Morgan, 186 U.S. 1, 9 (1902); Bowles v. Goebel, 151 F. 2d 671, 674 (C.A. 8th, 1945): "Discretion in a legal sense necessarily is the responsible exercise of official conscience on all the facts of a particular situation in light of the purpose for which it exists."

${ }^{14}$ An example of what must be shown is given by Moore v. Aderhold, 108 F. 2d 729, 731 (C.A. 10th, 1939): "It appears that he was charged with two felonious offenses and was a parole violator. In view of these facts, we cannot say the $[\$ 10,000]$ bail was excessive."

${ }^{16}$ United States v. Schneiderman, 102 F. Supp. 52 (S.D. Cal., 1951).

${ }^{16}$ Statute quoted in note 6 supra.

${ }^{17}$ Spector v. United States, 193 F. 2d 1002 (C.A. 9th, 1952); memo decision, Stack v, United States, 192 F. 2d 875 (C.A.9th, 1951). 
of indictment. ${ }^{18} \mathrm{He}$ had drawn an adverse inference from the refusal of the defendants to answer certain questions about their employment under a claim of privilege against self-incrimination. Finally, he had inferred from the Dennis decision that all Communists are dangerous. Each of these conclusions was held to be error. The Dennis decision, said the Court of Appeals, must not be taken to hold that all Communists advocate the overthrow of the government by force. It is fundamental law that a finding of fact is not binding upon persons not parties to the action. ${ }^{19}$ These errors in the reasoning of the District Court led it to conclude that the government had shown sufficient special circumstances for unusually high bail. The conclusion fell with the reasoning. The action of the Court of Appeals is analogous to a judgment notwithstanding the verdict by the trier of fact, Judge Mathes. ${ }^{20}$ Thus it appears that a hearing to set bail, whether for Communists or others, must conform to the usual due process requirements of an individual hearing with enough evidence to make the judgment reasonable.

Since congressional action to limit the right of Communists to bail is a distinct possibility, it may be proper to conjecture as to the constitutionality of such legislation. It has been argued that the proscription of "excessive bail" in the Eighth Amendment is meaningless unless it presupposes that some bail must be granted. ${ }^{21}$ Yet Congress long ago limited the right to bail to noncapital cases, which seems to indicate that the constitutional check, if there is one, does not limit the legislature. The drafters of the Amendment chose oblique language indeed if they intended an absolute guarantee of bail. It is more likely that the Amendment presupposed the familiar English common-law rules as to the availability of bail. The English Bill of Rights Act, ${ }^{22}$ the ancestor of our bail clause, did not give a right to bail but merely prohibited excessive bail..$^{23}$ The English law clearly permitted the legislature to determine the classes of cases in

${ }^{18}$ The trial court's deduction was probably one of membership in the Communist party which was better supported by the evidence at the hearing; but this, by the third error mentioned in the text, will not support the further inference of probable guilt under the Smith Act.

19 Spector v. United States, 193 F. 2 d 1002, 1006 (C.A. 9th, 1952): "Here again is clear error, for no principle of stare decisis or res judicata makes a finding of fact applicable to persons not parties to the action in which the finding is made."

${ }^{20}$ The defendants were ordered released by the Court of Appeals on usual recognizance. This is consonant with the desire for speed in bail cases. See Stack v. Boyle, 342 U.S. 1, 4 (1951).

${ }^{21}$ In his dissent in Carlson v. Landon, 342 U.S. 524, 556 (1952), Mr. Justice Black urges that the implied guarantee of the Amendment is a check upon both courts and legislature. As to the implied check upon the courts if Congress were to leave bail to judicial discretion, it would still seem to be constitutional to deny bail in proper case. But see Hudson v. Parker, 156 U.S. 277 (1895); United States v. Motlow, 10 F. 2d 657 (C.A. 7th, 1926); McKnight v. United States, 113 Fed. 451 (C.A. 6th, 1902).

\footnotetext{
221 Wm. \& Mary II, c. 2, \$1(10) (1689).

${ }^{23}$ See Carlson v. Landon, 342 U.S. 524, 545 (1952).
} 
which bail should be mandatory or unavailable. ${ }^{24}$ In all other cases bail was at the reasonable discretion of the courts and the question of reasonableness was reviewable by writ of habeas corpus. ${ }^{25}$ It seems, then, that the Eighth Amendment is an order to judges that they shall not evade the common-law requirement, restated in American statute, to give bail in proper cases by setting the amount too high. Today statute requires that bail be allowed before conviction in noncapital cases, but there is no constitutional obstacle to legislation removing bail altogether in given classes of cases or once more making the grant of bail a matter of judicial discretion in each case.

\section{II}

Admission to bail pending appeal, in contrast to bail before conviction, is at the discretion of the court. It "may be allowed." ${ }^{6}$ However, a liberal exercise of that discretion has long been accepted practice, ${ }^{27}$ with the defendant being entitled to a reasonable judicial determination of the bail question. ${ }^{28}$ If a substantial question is present, then only in case of great probability of escape or a serious danger of repetition of an atrocious crime should bail be refused..$^{29}$

In September, 1950, the Court of Appeals, Second Circuit, was asked in Williamson v. United States ${ }^{30}$ to revoke the bail of Communists pending appeal. The government's argument was that the defendants, convicted below under the Smith Act, with conviction affirmed by the instant court in United States v. Dennis, "s1 "have pursued and will continue to pursue a course of conduct and activity dangerous to the public welfare and National security of the United States." 32 A change in the danger presented by the defendants had been caused by the onset of the Korean conflict. The Court of Appeals referred the problem to the Circuit Justice by allowing a thirty day extension of bail. Mr. Justice

241 Steffen, History of Criminal Law in England 234-36 (1883); Qasem, Bail and Personal Liberty, 30 Can. Bar Rev. 378, 380-81 (1952).

${ }^{25}$ Consult Qasem, ibid., at 390-93.

${ }^{26}$ Fed. Rules Crim. Proc. 46(a)(2). "Bail may be allowed pending appeal or certiorari only if it appears that the case involves a substantial question which should be determined by the appellate court."

${ }^{27}$ United States v. St. John, 254 F. 794, 796 (C.A. 7th, 1918): "In fact bail has been so frequently granted after conviction that an erroneous impression has obtained with the bar that it is allowed as a matter of right."

28 "Detention pending the writ is only for the purpose of securing attendance of the convicted person after the determination of his proceedings in error. If this can or will be done by requiring bail, there is no excuse for refusing or denying such relief." McKnight v. United States, 113 F. 451, 453 (C.A. 6th, 1902). See United States v. Motlow, 10 F. 2d 657 (C.A. 7th, 1926).

${ }^{29}$ See Hudson v. Parker, 156 U.S. 277 (1895); Rossi v. United States, 11 F. 2d 264, 465 (C.A. 8th, 1926); Baker v. United States, 139 F. 2d 721, (C.A. 8th, 1944).

${ }^{30} 184$ F. 2 d 280 (C.A. 2d, 1950), noted in 64 Harv. L. Rev. 662 (1951).

31 United States v. Dennis, 183 F. 2d 201 (C.A. 2d, 1950).

32 184 F. 2d 280, 281 (C.A. 2d, 1950). 
Jackson first found that there was a substantial question for review by the Supreme Court, namely the constitutionality of the Smith Act. In answer to the government's public welfare argument, he doubted whether a repetition of the alleged actions, with the admitted substantial question as to guilt, would justify revocation of the bail ${ }^{33}$ Not resting on this ground, Mr. Justice Jackson said of the activities complained of, "I find them to consist entirely of making speeches and writing articles.... They do not contain any advocacy of violent overthrow of the Government." ${ }^{44}$ Finding neither precedent nor convincing reasons for the judiciary "to protect society from predicted but unconsummated offenses," the Justice upheld the admission of the defendants to bail pending appeal to the Supreme Court..$^{35}$

The Williamson opinion reaffirmed the traditional position that bail pending appeal, when a substantial question is present, is at the discretion of the deciding official, who is to be overruled only when the discretion is abused. ${ }^{36}$ Going further, the Ninth Circuit, in Bridges v. United States, ${ }^{37}$ had said one month before, "where a meritorious question exists, bail becomes a matter of right, not of grace."38 In response to this statement, Mr. Justice Jackson said in the Williamson opinion, "I cannot accept this view that the presence of a substantial question makes bail mandatory ... [T]he Rule permits bail only in circumstances warranted by sound judicial discretion." 39 To support this view, Justice Jackson pointed out the change made during the drafting of the rule from "Bail shall be allowed" to "Bail may be allowed" pending appeal. Whether

38 Ibid., at 283: "Another difficulty with the government's position ... is that while a substantial question exists as to whether they have been lawfully convicted it is equally doubtful whether repetition, if it be such, is a crime."

34 Ibid., at 283 n. 8, says further, "The Smith Act purports to authorize prosecution of publication with intent to cause overthrow of the Government. Section 2(a)(2), 54 Stat. 671. These defendants were not indicted under this section." The fact that Mr. Justice Jackson upheld the Communists' right to bail even though later he took a serious view of that conspiracy in Dennis v. United States, 341 U.S. 494, 561 (1951), is encouraging to those fearing destruction of our civil liberties.

${ }^{35}$ A decision in the Ninth Circuit a month earlier, Bridges v. United States, 184 F. 2d 881 (C.A. 9th, 1950), had set forth the same arguments as the Williamson opinion. The government unsuccessfully argued that the status of a bailed defendant should be assimilated to a person on probation. Even with the Korean hostilities, the fear for the interests of the United States was held to be insufficient ground to deny bail to Bridges.

${ }^{36}$ United States v. Motlow, 10 F. 2d 657 (C.A. 7th, 1926); Zydok v. Butterfield, 187 F. 2d 802 (C.A. 6th, 1951) (an immigration case). The Allowance of Bail Pending Appeal, 31 B.U.L. Rev. 244 (1951).

${ }^{37} 184$ F. 2d 881 (C.A. 9th, 1950).

${ }^{38} \mathrm{Tbid}$., at 884 . The earlier precedent relied on was a general statement in Hudson v. Parker, 156 U.S. 277, 285 (1895): "The statutes of the United States have been framed upon the theory that a person accused of crime shall not, until he has finally been adjudged guilty in the court of last resort, be absolutely compelled to undergo imprisonment or punishment, but may be admitted to bail, not only after arrest and before trial, but after conviction and pending writ of error."

${ }^{39}$ Williamson v. United States, 184 F. 2d 280 n. 4 (C.A. 2d, 1950). 
the Ninth Circuit merely failed to distinguish right to bail from right to reasonable exercise of judicial discretion is left in doubt. Nevertheless, by the better view, ${ }^{40}$ if a substantial question as to guilt exists bail can be denied pending appeal on reasonable proof that the defendant will not be producible for sentence if bailed.

The courts consciously use the "substantial question" bail requirement to discourage delay through frivolous appeals. ${ }^{41}$ As the area of subversive activity becomes more clearly defined by court decisions, it is probable that the requirement of a substantial question as to guilt will become more stringent. The area of allowable conduct could shrink to the extent that the provision for bail pending review would become a nullity for those convicted of subversive activity.

The 82d Congress has had before it legislation denying the right to bail pending appeal to persons convicted of subversive activity and setting bail at an absurdly high amount. ${ }^{42}$ The discussion of the Eighth Amendment in section I above indicates that these measures are probably constitutional, since the prohibition of "excessive bail" was, historically, a curb only on sheriffs or judges..3

\section{III}

With rights which depend, by their nature, on at least some discretion of elected officials, ${ }^{44}$ abuse is not entirely avoidable. ${ }^{45}$ The courts have recognized the need for speedy review of bail problems by providing for appeals from the denial of a motion ${ }^{46}$ or for direct applications to a higher court. Within the limits of this system, the cases indicate that the rights of the citizen Communist to be bailed are protected as fully as those of the ordinary criminal. However, the protection indicated by the Stack and Williamson decisions is not equally extended to the alien.

${ }^{40}$ These two cases have been extensively commented on with the uniform conclusion that the Williamson view is the correct interpretation of the statute. E.g., see notes in 64 Harv. I. Rev. 662 (1951); 26 N.Y.U. L. Rev. 191 (1951); 3 Stanford L. Rev. 167 (1950).

${ }^{41}$ See D'Aquino v. United States, 180 F. 2d 271 (C.A. 9th, 1950); United States v. Motlow, 10 F. 2d 657 (C.A. 7th, 1926); McKnight v. United States, 113 Fed. 451 (C.A. 6th, 1902).

${ }^{42}$ H.R. 4780, 82d Cong. 1st Sess. (1951), fixes permanent bail of one million dollars for each day a convicted Communist remains away from jail. H.R. 4776, 82d Cong. 1st Sess. (1951), provides that no person convicted of treason, sedition, subversive activities, shall be admitted to bail or released from custody until a final judgment upon appeal. H.R. 4826, 82d Cong. 1st Sess. (1951), prohibits bail pending appeal or certiorari after conviction of espionage, treason, sedition, or of conspiracy to commit any such offense.

${ }^{43}$ Authorities cited notes 24 and 25 supra.

44 Consult Beely, The Bail System in Chicago 160-65 (1927), for a criticism of the trend in American law away from magisterial discretion towards definite rules and a criticism of the usual paucity of facts on which the bail determination is made.

${ }^{45}$ Hawaiian District Judge Delbert E. Metzger was indirectly threatened with dismissal by Sen. Joseph C.O'Mahoney when he refused to impose excessive bail on seven persons arrested as Communists. N.Y. Times $\S 1$, p. 12, col. 3 (Aug. 30, 1951); Judges or "Mere Instruments"?, 173 Nation 202 (Sept. 15, 1951).

${ }^{46} \mathrm{~A}$ denial of a motion to reduce amount of bail was held to be reviewable as a final decision in Stack v. Boyle, 342 U.S. 1, 5 (1951). 
Many constitutional rights have been extended to aliens. ${ }^{47}$ Deportation, however, has been clearly distinguished as a power of the sovereign free of most constitutional limitations. ${ }^{48}$ In Wong Wing $v$. United States, $1896,{ }^{49}$ the Supreme Court ruled that aliens could not be sentenced to hard labor in deportation proceedings, but that they could be confined without bail pending determination of their deportability. ${ }^{50}$ The Immigration Act of 1917 declared that an alien "may be released under a bond." This statute was interpreted by different circuits either as requiring the Attorney General to grant bail ${ }^{52}$ or as giving him discretion to grant bail. ${ }^{53}$ The discretionary interpretation held that the administrative denial of bail would be reversed where the decision was without reasonable foundation. ${ }^{54}$ In 1950, Congress resolved this jurisdictional split by the wording of the new statute, "may, in the discretion of the Attorney General be continued in custody; or be released under bond." ${ }^{55}$

Under this new provision, in March, 1952, the Supreme Court, in Carlson v. Landon, ${ }^{58}$ approved the detention of an alien without bail pending a deportation hearing, regardless of the time involved, upon the Attorney General's ruling

${ }^{47}$ E.g., right to property through the 14 th Amendment, Yick Wo v. Hopkins, 118 U.S. 356 (1886); the privilege against self-incrimination, Schoeps v. Carmichal, 177 F. 2d 391, 400 (C.A. 9th, 1949), cert. denied, 339 U.S. 914; freedom of speech, Bridges v. Wixon, 326 U.S. 135 (1945).

18 Harisiades v. Shaughnessy, 342 U.S. 580 (1952). See Wong Wing v. United States, 163 U.S. 228 (1896).

\section{U.S. 228 (1896).}

${ }^{50}$ Ibid., at 235: "We think it clear that detention, or temporary confinement, as part of the means necessary to give effect to the provisions for the exclusion or expulsion of aliens would be valid. Proceedings to exclude or expel would be vain if those accused could not be held in custody pending the inquiry into their true character and while arrangements were being made for their deportation."

5139 Stat. 890 (1917), 8 U.S.C.A. $\$ 156$ (1942). A like provision in the Immigration Act of $1907, \S 20,34$ Stat. 904,905 (1907), as amended, 8 U.S.C.A. $\$ 156$ (Supp., 1951), was the first permissive bail in deportation proceedings.

62 Prentis v. Manoogian, 16 F. 2d 422 (C.A. 6th, 1926).

${ }^{63}$ United States ex rel. Pirinsky v. Shaughnessy, 177 F. 2d 708 (C.A. 2d, 1949); United States ex rel. Potash v. Dist. Director of Immigration \& Naturalization, 169 F. 2d 747 (C.A. 2d, 1948); United States ex rel. Zapp v. Dist. Director of Immigration \& Naturalization, $120 \mathrm{~F}$. 2d 762(C.A. 2d, 1941).

54 United States ex rel. Potash v. Dist. Director of Immigration \& Naturalization, 169 F. 2d 747, 751 (C.A. 2d, 1948): "The discretion of the Attorney General which we held to exist in the Zapp case is interpreted as one which is to be reasonably exercised upon a consideration of such factors, among others, as probability of the alien being found deportable, the seriousness of the charge against him, if proved, the danger to the public safety of his presence within the community, and the alien's availability for subsequent proceedings if enlarged on bail."

${ }^{65}$ Internal Security Act of 1950, at $\$ 23,64$ Stat. 1010 (1950), 8 U.S.C.A. 156(a) (Supp., 1951): "Pending final determination of deportability of an alien taken into custody under warrant of the Attorney General, such alien may, in the discretion of the Attorney General (1) be continued in custody; or (2) be released under bond ... ; or (3) be released on conditional parole."

ธ8 342 U.S. 524 (1952). 
that he is a threat or danger to the public interest. The mere showing of Communist party membership was found to be sufficient to make the exercise of the Attorney General's discretion reasonable, for the Internal Security Act made Communist party membership alone sufficient ground for deportation. ${ }^{57}$ This holding is in direct contrast to the emphasis in the Stack decision on a personalized hearing. In its attempt to justify this legislative invasion of what is arguably a constitutional right, the Carlson majority opinion goes very far in advancing the very arguments, such as the concept of a continuous political crime which is certain to be continued, which have been so vigorously rejected by the Court in other contexts. "Detention is necessarily a part of this deportation procedure. Otherwise aliens arrested for deportation would have opportunities to hurt the United States during the pendency of deportation proceedings." 188

Two other provisions of the Internal Security Act have been applied to the right of an alien to bail. The Act provides for exclusion or deportation for confidential reasons on certification by the Attorney General that the secrecy is in the national interest. ${ }^{59}$ This provision had been substantially embodied in a wartime presidential proclamation. ${ }^{60}$ In 1949 this executive power was used to allow denial of motions for bail on confidential reasons. ${ }^{61}$ Naturally, if secrecy is to be obtained, it must be present at all stages of a proceeding. The remaining provision of the act which has been applied to a bail problem is that which orders the Attorney General, if he is unable to deport an alien six months after the final order, to release the alien under supervision..$^{62}$ In the 1952 case of Mezei v. Shaughnessy, ${ }^{63}$ the Second Circuit extended the provision beyond its literal protection of deportable aliens to include exclusion proceedings. The relator, attempting to enter the country, had been detained on Ellis Island for twenty-two months after a final exclusion order based on secret reasons, because

5764 Stat. 1006 (1950), 8 U.S.C.A. \$137(2), (6) and \$137-3(a) (Supp., 1951).

${ }^{58} 342$ U.S. 524, 538 (1952). The decision was 5 to 4 . Mr. Justice Frankfurter dissented on grounds of statutory interpretation, pointing out, "Moreover, in deportation cases-as compared, for example, with prosecutions under the Smith Act-the consideration that the individuals concerned may depart from the country is minimized in significance, first, because compulsory departure from the United States is just what they are contesting, and secondly, if they do depart, the purpose of the deportation proceedings is realized." Thid., at 558, 563.

${ }^{69} 64$ Stat. 1006 (1950), 8 U.S.C.A. § 137-4 (Supp., 1951).

${ }^{60}$ Presidential Proclamation No. 2523 (1941), authorized by 40 Stat. 559 (1918), as amended, 55 Stat. 252 (1941), 22 U.S.C.A. $\$ 223$ (1941). Applied to effect deportation in Knauff v. Watkins, 173 F. 2d 559 (C.A. 2d, 1949).

61 Knauff v. Shaughnessy, 338 U.S. 537 (1950).

0264 Stat. 1010 (1950), 8 U.S.C.A. §156(a), (b) (Supp., 1951). Former case law held that conditions of supervision other than bail could not be required, and that bail was mandatory. Petition of Brooks, 5 F. 2d 238 (D.C. Mass., 1925); United States ex rel. Janavaris v. Nicolls, 47 F. Supp. 201 (D.C. Mass., 1942). Bail during the six month period is at the discretion of the Attorney General. United States ex rel. Dzuro v. Dist. Director of Immigration \& Naturalization, 102 F. Supp. 704 (S.D. N.Y., 1951).

os 195 F. 2d 964 (C.A. 2d, 1952). 
no country could be found willing to accept him. The court ordered a new hearing to set reasonable conditions of bail..$^{4}$

The extent of the judicial abdication of power to review bail determined by the Attorney General is not clear in the Carlson decision. The cases before the Internal Security Act of 1950 had held that the discretion of the Attorney General was reviewable, much the same as bail determination in criminal cases. The Court in the Carlson case said, "We think the discretion [to allow bail] reposed in the Attorney General is at least as great as that found by the Second Circuit in the Potash ${ }^{65}$ case to be in him under the former bail provision. It can only be overridden where it is clearly shown that it 'was without reasonable foundation.' "'66 In sympathy with the arguments of special danger, the Court seems to have devised a new purpose of bail: "Hearings are had, and [the Attorney General] must justify his refusal of bail by reference to the legislative scheme to eradicate the evils of Communist activity." ${ }^{\prime 67}$

\section{IV}

Besides setting the amount higher than a defendant can meet, or denying bail altogether, courts have, at times, virtually denied bail to a prisoner by disqualifying the surety or the bond offered. In view of the trend in the United States toward professional bonding companies and cash bail, ${ }^{68}$ the assertion of this power by the courts against Communists may seem unjust. The Federal Rules of Criminal Procedure, Rule 46(d), provides:

A person required or permitted to give bail shall execute a bond for his appearance.

- One or more sureties may be required, cash or bonds or notes of the United States may be accepted and in proper cases no security need be required.

Classically, bail is a three party transaction. ${ }^{69}$ In consideration for the surety's promise secured by a money bond that he will produce the defendant in court on the named day, the state agrees to release the accused into the private custody of the surety..$^{70}$ The practice of releasing a suspected criminal into private custody has a very long history in Anglo-American law, having originated in the tribal customs of the Saxons at a time when private persons were

64 Ibid., at 968: "That no explicit provision is applicable in exclusion proceedings against aliens not already admitted does not, we think, signify another policy as to such persons." Judge $\mathrm{L}$. Hand, dissenting at 970, argues that the distinction should be made: "I do not believe that an alien so situated can force us to admit him at all."

${ }^{65}$ United States ex rel. Potash v. Dist. Director of Immigration \& Naturalization, $169 \mathrm{~F}$. 2d 747 (C.A. 2d, 1948).

${ }^{\infty}$ Carlson v. Landon, 342 U.S. 524, 540 (1952).

67 Thid., at 543. Accord: United States ex rel. Potash v. Dist. Director of Immigration \& Naturalization, quoted op. cit. supra note 54.

${ }^{68}$ In re Carter, 192 F. $2 d$ 15, 17-20 (App. D.C., 1951), discusses a professional bonding company statute, D.C. Code (1940), $\$ \$ 23-602,23-608$.

"See Reese v. United States, 9 Wall. (U.S.) 13 (1869).

${ }^{70}$ Fitzpatrick v. Williams, 46 F. 2d 40 (C.A. 5th, 1931). 
probably the only available guardians. ${ }^{71}$ Later the motivation became the desire to avoid imprisonment of an accused before final conviction.

The private jailor concept of the surety is retained with full vigor in England..$^{72}$ In the United States, though, there has been a trend towards a mere money contract, which has been justified by the frequent difficulty in our society of readily finding a willing personal surety. The surety does not, indeed cannot, act as a literal jailor, though he does have affirmative duties and powers over his principal. ${ }^{73}$ An indication of this trend towards a money concept is the emergence of professional bonding companies giving bail as a business. Another sign of the trend is the power of the determining body, at its discretion, to dispense with the surety altogether and require only cash bail. Under this procedure, the defendant posts his own bond and assumes the loss if he should abscond. Similarly, it is no longer against public policy in many jurisdictions for the accused to indemnify his surety, thus shifting the risk of loss to himself. ${ }^{74}$ The mere money concept is not law, however. Both financial ${ }^{76}$ and moral ${ }^{76}$ qualifications are demanded of the surety.

The most prominent case rejecting the concept of the surety as a substitute jailor is Leary v. United States. ${ }^{77}$ There the Supreme Court rejected the commonlaw rule invalidating a private contract of indemnity between a criminal defendant and his bail, saying, "The interest to produce the body of the principal

71 The Queen Against Badger, Esq., and Cartwright, Clerk, [1843] 4 Q.B. 468, 472: "The law is clear, and is as old as the Statute of Westminster the First, 3 Ed. 1, c. 15. Lord Coke, in his commentary upon that statute, ( 2 Inst. 191), says that 'to deny a man plevin that is plevisable and thereby detain him in prison is a great offense, and grievously to be punished.' And Lord Hale adopts the same remark: and Hawkins (Part 2, c. 15, s. 13(b)) speaks of refusals of bail as an indictable offense. Blackstone, referring, ( 4 Comm., c. 22, p. 297) to the ancient statute, the Habeas Corpus, (c) and the Bill of Rights (d), calls it 'an offense against the liberty of the subject." "

72 Consult: Qasem, Bail and Personal Liberty, 30 Can. Bar Rev. 390-93 (1952); DeHaas, Concepts of the Nature of Bail in English and American Criminal Law, 6 U. of Toronto L.J. 385 (1946). Indemnity contracts and corporate sureties are both forbidden, though statute does allow discretionary cash bail: The Bail Act, 61 Vict., c. 7, 81 (1898).

${ }^{73} \mathrm{He}$ has a right to arrest the principal. 62 Stat. 821 (1948), 8 U.S.C.A. $\$ 3142$ (1948).

74 Consult Indemnification Contracts in the Law of Bail, 35 Va. L. Rev. 496 (1949).

75 The financial requirements for the surety have been explicitly delineated. Title to all property posted must be proved, and the court must be satisfied that the surety is financially responsible. Fed. Rules Crim. Proc. 46(e): "Every surety except a corporate surety which is approved as provided by law, shall justify by affidavit and may be required to describe in the affidavit the property by which he proposes to justify and encumbrances thereon, the number and amount of other bonds and undertakings for bail entered into by him and remaining undischarged, and all his other liabilities. No bond shall be approved unless the surety thereon appears to be qualified." Corporate sureties must meet the financial requirements specified in 61 Stat. 646 (1947), 6 U.S.C.A. \$§ 6-14 (Cum. Supp., 1950).

${ }^{78}$ The moral sufficiency of a bonding company is largely a matter of business honesty. If the company can show a record of upright conduct in its business affairs and freedom from undercover connections with criminals, it fulfills the moral qualifications. In re Carter, 192 F. 2 d 15 (C.A. 2d, 1951); United States v. American Bonding Co., 39 F. $2 d 428$ (C.A. 9th, 1930).

7224 U.S. 567 (1912). 
in court is impersonal and wholly pecuniary."78 The monetary concept of the bail surety was carried even further in the case of Rowan $v$. Randolph, ${ }^{79}$ where the Seventh Circuit ruled that a district judge did not have the discretion to refuse to accept cash bail where a money bond with surety had been ordered. ${ }^{80}$ The effect of the Rowan decision has been negated by the Federal Rules of Criminal Procedure, specifically empowering the judge setting bail to require a surety. As to the indemnity contract, it can be argued that the Leary doctrine strengthens the need for the courts to demand morally qualified sureties: Since the escaped defendant is to pay for the forfeited bond, only a moral obligation will give the surety any function. The basic fact that the surety does not keep close watch over the principal, however, lends strong force to the Leary position. Actually, the broad Leary dictum has been rejected, as indicated by Concord Casualty and Surety Co. v. United States. ${ }^{81}$ Upholding the refusal of the bonds of a particular surety company which had allowed prior escapes, the court said, "When a defendant is called upon to pay his obligation to society, it is not the sum of the bail bond that society asks for, but rather the presence of the defendant for imprisonment." 82

What then remains as the function of the surety in the law of bail? Is he merely a moral hope or perhaps a judicial tool to deny freedom by bail at will? In contrast to other rules of bail, those governing the qualifications of a surety were being questioned when the Communist cases brought new considerations. Let us turn to the recent Federal cases to see how the sureties offered by Communists have been treated.

Alleged Communist affliation was the basis of disqualification of an individual surety by the Immigration authorities in United States ex rel. Bittelman v. District Director of Immigration and Naturalization..$^{83}$ The defendant had been arrested for deportation as a Communist. The individual surety offered was eminently qualified except that his union was a member of the International Workers' Order, which is on the Attorney General's proscribed list of subversive organizations. ${ }^{84}$ The district court held that the denial of bail on that ground alone was an abuse of discretion.

The Bittelman ruling is an example of the principle that questions concerning

${ }^{78}$ Ibid., at 575 , thus overruling such cases as United States v. Simmons, 47 Fed. 575 (S.D• N.Y., 1891), where bail was refused on the ground that the indemnity contract disqualified the bail.

79268 F. 529 (C.A. 7th, 1920). The statute construed is the former bail provision, Rev. Stat. $\$ \$ 1014,1015$ (1878).

${ }^{80}$ Accord: United States v. Widen, 38 F. $2 d 517$ (N.D. Ill., 1930).

${ }^{81} 69$ F. $2 d 78$ (C.A. 2d, 1934). 1930).

82 Ibid., at 81. See also United States v. American Bonding Co., 39 F. $2 d 428$ (C.A. 9th,

8399 F. Supp. 306 (S.D. N.Y., 1951), a proceeding under the Internal Security Act of 1950.

"His first proffered surety, the Civil Rights Congress, had been refused. 
the qualifications of the surety are not to be decided in advance as by disqualifying a class..$^{85}$ Of course, if the court has reasonable grounds to believe that the proposed surety intends to secure the escape of the defendant, ${ }^{86}$ or if the surety has a record of allowing prior escapes, ${ }^{87}$ he may be rejected. In Christoffel $v$. United States, ${ }^{88}$ the Civil Rights Congress was rejected as a source of a money bond because of prior escapes of criminals bailed to them. The court rejected the defendant's argument that, since the bail order had made a surety optional, the qualifications of the source of deposited money or bonds cannot be questioned. The Government had changed its attitude toward Christoffel with the onset of the Korean war and sought this indirect way of revoking bail. To the extent of disqualifying this one source of money, the government was successful. However, the court refused to issue a new order requiring a surety, or to revoke bail altogether, on the same reasons as the Second Circuit advanced in the Williamson case. ${ }^{89}$ The prosecution failed to show the necessary probability of escape. If Christoffel could find a new source of money, the original bail order was still effective. The basic purpose of bail was upheld: freedom on such conditions as give good probability of reappearance.

In United States v. Flynn, ${ }^{90}$ bail posted by the Civil Rights Congress was revoked when the trustees of the bail fund refused to answer questions relating to the ultimate source of the fund. The court argued that the trustees' refusal revealed a "disregard of their responsibilities as sureties for the discovery and presentation before the court of their principals." argued that bail funds donated to the surety by other persons without consideration provide no incentive to produce the accused, since the surety bears no risk of loss. ${ }^{92}$ The court's disregarding of the Communist affliation is in line with the Bittelman rejection of that argument two weeks later.

85 "But to say in advance that no individual surety will be accepted is to pre-judge that issue which he is entitled to tender and have decided in good faith." United States v. Mule, 40 F. 2d 503 (C.A. 2d, 1930).

88 United States v. Lee, 170 Fed. 613 (S.D. Ohio, 1909).

${ }^{87}$ Concord Casualty and Surety Co. v. United States, 69 F. 2d 78 (C.A. 2d, 1934).

88196 F. 2d 560 (App. D.C., 1951).

${ }^{89}$ Ibid., "... the court cannot properly revolke the order or by modification add to the conditions defined therein except upon a showing of the existence of factors which may lessen the dependability of the appearance of Christoffel when required to appear."

30190 F. 2 d 672 (C.A. 2d, 1951).

${ }^{91}$ Ibid., at 673. The trustees' reluctance can probably be explained on the ground that disclosure would have implicated many donors who preferred to remain anonymous. In United States v. Field, Hammett, \& Hunton, 193 F. 2d 92 (C.A. 2d, 1951), the proposed sureties were cited for contempt for the refusal. As a defense to the contempt proceedings, the three defendants invoked their constitutional privilege against self-incrimination. However, the court held that the privilege had been abrogated when the defendants undertook the bail contract.

$\$ 2$ See United States v. Lee, 170 Fed. 613 (S.D. Ohio, 1909). But cf. United States v. Werner, 47 F. 2d 351 (N.D. Okla., 1931), where donated bail funds were treated as the defendant's own money. 
Thus the federal courts have spoken on the purpose and duties of the surety. Yet, is any real function served by shifting the issue from the character of the defendant to the morals of the source of the bond? As in the Christoffel case, there can occasionally be a relatively rapid determination of the acceptability of a particular surety based on past conduct. By the licensing of bonding companies, perhaps many hearings are condensed into one. The character of the surety, at least, need only be considered once. In a hope of improving the determination of the issue of the surety's character, further growth of appellate rules to govern the magisterial discretion can be expected.

The possibility of disqualifying a defendant's only surety may deprive him of his right to bail prior to conviction. Resolutions introduced in the $82 \mathrm{~d}$ Congress proposed the automatic disqualification of any surety known to have affiliations with any organizations listed as subversive by the Attorney General. ${ }^{93}$ The Civil Rights Congress has been found to lack the qualifications of a proper surety by federal courts. ${ }^{94}$ Perhaps a surety's subversive character or record of permitting prior escapes should have no bearing upon allowing the surety to post bond for a defendant. Sureties do not act as jailors despite the resurrection of the jailor concept by the courts; the relevant consideration is the character of the defendant, not the surety. It may be argued that, while sureties do not perform a jailor function, they do, in effect, wager their money that a defendant will not flee, and that therefore a morally qualified surety acts as a short-cut, bonded trier of fact in deciding whether to post bond for a particular defendant. There are two answers to this argument: (1) Since the Federal Rules of Criminal Procedure guarantee bail prior to conviction in noncapital cases, denying bail through disqualification of the only available surety runs counter to the statutory guarantee ${ }^{95}(2)$ It is quite possible that "reputable" sureties refuse to post bond for a Communist defendant not through fear that he will escape but through fear of public disapproval or personal aversion to alleged subversives.

\section{$\mathrm{V}$}

The impact of the Smith Act and the Internal Security Act cases upon the traditional law of bail does not seem to have altered the law significantly in most areas. The right to bail before conviction has been reaffirmed despite the gov-

${ }^{93}$ H.R. 5041, 82d Cong. 1st Sess. (1951) prevents the taking of bail which originates with subversive individuals or organizations, and prohibits bail, pending appeal or certiorari, after conviction of espionage, treason, sedition or subversive activities. H.R. 4821, 82d Cong. 1st Sess. (1951) provides that bail shall not be taken from a surety listed as subversive by the Attorney General of the United States.

" Christoffel v. United States, 196 F. 2d 560 (App. D.C., 1951); United States ex rel. Bittelman v. District Director of Immigration \& Naturalization, 99 F. Supp. 306 (S.D. N.Y., 1951).

${ }^{95}$ Many state constitutions make bail mandatory before conviction. Under such provisions, a captious disqualification of surety has been found unconstitutional. Ex Parte Stegman, 163 Atl. 422, 427 (N.J., 1932); Ex Parte Ruef, 8 Cal. App. 468, 469-70, 97 Pac. 89,90 (1908). 
ernment's arguments that the Korean war, the Dennis case, and the flight of four of the Dennis defendants have indicated the danger posed to our society by Communists, the nature of their conspiracy and the likelihood of flight. In the face of the same government arguments, bail has been extended to Smith Act defendants pending appeal where a substantial question for review existed. Interestingly, however, these same arguments have proved effective in alien deportation cases. Although the arguments seem no more convincing in this area, the denial of bail to deportees is unexceptional on precedent. The vice lies in the law concerning aliens, not in that of bail for Communists. The only area in which it is arguable that the Communist problem has caused the courts to change their attitude on bail is that of disqualification of sureties. The unrealistic jailor concept of the surety seemed almost to have been discarded when it was revived to justify disqualification in Communist cases. With the possible exception of the surety cases, then, the federal courts, and particularly the Supreme Court, have resisted remarkably well the pressure to alter the rules of bail to disadvantage unpopular defendants. 